\title{
AN OUTBREAK OF HEARTWATER IN \\ WEST AFRICAN DWARF LAMBS ON PASTURE
}

\author{
A. O. AYENI \\ Department of Animal Science, Obafemi Awolowo University, Ile-Ife
}

(Received 31 December 1990, accepted 5 August 1991)

\begin{abstract}
An outbreak of Heartwater disease in young West African Dwarf ram/lambs on pasture in Ile-Ife is reported. The outbreak which started 2 weeks after being put to pasture lasted 4 weeks. It affected seven out of 24 lambs put to an experimental pasture. The remaining animals in the unit (about 250) were apparently not affected. In 3 of the cases Cowdria ruminantium organisms were demonstrated in the endothelial cells of the jugular vein. Ticks removed from the animals and ground in sterile saline produced Heartwater disease in susceptible goats.
\end{abstract}

\section{INTRODUCTION}

Although the widespread distribution of heartwater in Nigeria has long been established (Anon, 1945) only one case report of an outbreak in Southern Nigeria has been documented so far (Isoun et al. 1974). The transmission agent in Nigeria is Amblyomma variegatum which transmits the disease transstadially (Ilemobade \& Leeflang, 1977). The present paper reports on an outbreak of Heartwater in pastured lambs on the Obafemi Awolowo University Teaching and Research Farm. The outbreak which occured during the middle of the dry season lasted for about 4 weeks.

\section{MATERLALS AND METHODS}

Twenty four West Afican Dwarf rams aged 6 to 12 months each weighing approximately $15 \mathrm{~kg}$ were selected from the flock housed in the Sheep and Goat Unit. Although pasture was avilable at the Unit (Cynodon sp), the diet of these animals consisted mostly of concentrated feed prepared by the farm. They were treated with a therapeutic dose of anthelminthic Thiaben$z^{2 o l e}{ }^{(R)}$ and kept indoors with no access to pastures for four weeks prior to being put on

Nigeria Journal of Animal Production 18 (1991) pastures in order to avoid reinfection with helminths. During that period their growth rate was $50 \mathrm{~g} / \mathrm{d}$. On a weight basis the rams were divided into four groups of six animals and put to the pasture. Two groups were infected with $2000 \mathrm{~L}_{3}$ Haemonchus contortus on day 21 post pasturing $(\mathrm{p} / \mathrm{p})$ and the other two groups were left uninfected.

The pasture, 1.6 hectares, was planted with Panicium maximum (variety S112) over five years ago. Although grazed by cattle for several years the paddocks have been ungrassed for two years prior to the commencement of this study. To make the patures, which were over grown, suitable for sheep grazing experiment, the grass was slashed twice at a fortnightly interval. As a result there. was a substantial litter layer (up to 5 $\mathrm{cm}$ ) in some parts of the paddocks. The pasturc was divided into four paddocks each sorrounded by young Gliricidia sepium trees. The paddocks were rouged to remove the few scattered wceds. During the following 5 weeks on the pasture the mean growth rate of the lambs excecded $80 \mathrm{~g} / \mathrm{d}$. The lambs were not dipped before heing put (o) pasture and they were moderately infested with ticks (Amblyomma variegatum .

\section{RESULTS}

Case 1: Grower ram No. 178 was found trapped in the fence on day $13 \mathrm{pp}$. There was neither fever, anacmia nor diarrohea. It was alaxic and later in the day it was unable to stand. By day 15 $p p$, it was moribound and had to be sacrificed. Autopsy revealed only hydropericardium.

Case 2: On day 2.3 p.p, a second sheep was found recumbent with the same signs as casc 1. Salt water was offered and drunk hut there was no im. provement. Magnesium Sulphate (10)g in water) was given subcutanesly on day 27 with no marked improvement. On day $2 x$ the treatment 
repeated and in addition $100 \mathrm{ml}$ of $\mathrm{MFC}^{(\mathrm{R})}$ Solution (May and Baker, 25\% Calcium borogluconate, $5 \%$ Magnesium hypophoshite ,20\% Dextrose in distilled water) was administered intravenously $(40 \mathrm{ml})$ and intraperitoneally $(60 \mathrm{ml})$. There was no improvement. The animal died on day 28 . Post mortem showed hydropericardium and heart muscle degeneration.

Case 3: On day 27, the third case (Grower 287) was found recumbent. The animal staggered after its mates with great effort. As in both previous cases the ataxia affected all four limbs at the same time. On the same day, 5g Magnesim Sulphate was given subcutaneosly and ten minutes later the treatment was repeated. After 25 minutes a slight improvement was observed. On day $28,100 \mathrm{ml}$ of MFC was given $(40 \mathrm{ml}$ i.v., $60 \mathrm{ml}$ i.p). There was no improvement. Sulphonamide $5 \mathrm{ml}$ Theracanzan $\left({ }^{*}\right)^{*}$ was given on each subsequent day along with repeated doses of MFC. There was progressive deterioration and the animal was killed on day 31 . Post mortem showed kidney and Heart muscle degeneration and Hydropericardum.

Case 4: (Grower 220). The first signs were observed on day 35. Unlike the other cases, the characteristic ataxie developed progressively, the animal being unable to run with its mates for about a week while "staggc ring". $100 \mathrm{ml} \mathrm{MFC} \mathrm{was}$ administered as above plus $10 \mathrm{~g}$ Magnesim oxide orally. During treament the animal had convulsive episodes.

It was noted that during the previous week the animal had an abnormal gait thought to be due to a swollen scrotal sac. After treatment there was no improvement. Copper Sulphate $(1.5 \mathrm{~g}$ orally in water) was given on day 37 with no effect. On day $38,5 \mathrm{ml}$ TM-LA ${ }^{\mathrm{R} * *}$ was administerd i.m. On day 41 the animal preffered to sit and followed its mates only with difficulty. On day 42 it was recumbent. It was killed on day 43. Post mortem revealed no gross abnormalities. Giesmastained scrapings of the intime of the jugular vein showed massive intrraendothelial invasion with Cowdria numinantium organisms.
Case 5: On day 35, grower 284 was observed to be unable to keep up with its mates. It was unsteady and nervous when approached. Treatment with MFC and Magnesium oxide produced no improvement. Phosphates and trace minerals (Tonophosphen $5 \mathrm{ml}$ ) also had no effect. $5 \mathrm{ml}$ TM-LA ${ }^{(R)}$ was also administered i.m. on day 37 the animal was recumbent and blind and it died on the night of day 37/38. Postmortem revealed brown fluid in the abdomen and thorax; soft and petechiated, kidneys, hydropericardium with bleeding into the pericadium, soft heart muscle,soft and friable liver, distended gall bladder and petechiae in the abomasum (the animal had been artificially infected with 2000L3 Haemonchus contortus 14 days before onset of symptoms). Like in case 4 , there was invasion of intima of the jugular vein by $C$. numinatium.

Case 6: On day 36, grower 175 was found recumbent at 11.00a.m having been observed fit and well at $8.00 \mathrm{a} . \mathrm{m}$ MFC and Magnesium oxide were administered immediatelly but with no effect. On day 37 the treatment was repeated along with $5 \mathrm{ml}$ TM-LA ${ }^{(\mathrm{R})}$ i.m with no effect. The animal's condition rapidly dèteriorated and it was killed on day 38. Before death the animal was tetanic, starring and with its head held stiffly to one side.At postmortem there were small necrotic areas in the liver. Findings in the jugular vein were similar to those in case 4 and 5 .

Case 7: (Grower 157).On day 42 the animal was observed to be staggering and unable to keep up with its mates, but by evening the animal had fully recovered even without treatment. However, it is noteworthy that between days 35 and 42 the animal lost $1.2 \mathrm{~kg}$ but between days 42 and 49 gained $1.8 \mathrm{~kg}$.

\section{FOLLOW - UP STUDIES}

Engorged female ticks were collected from case 7,and from 2 of the other pastured animals that were clinically healthy. These were ground seperately in sterile phosphate buffered saline (PBS) according to the tecnique of Ilemobade 
and Leeflang (1978).A volume of $5 \mathrm{ml}$ of each suspension was injected into 2 susceptible goat which eventually developed clinical heart water disease.

\section{DISCUSSION}

It has been established that animals occasionally come down with fatal heartwater when subjected to stress situations like vaccinations, dipping, transportation and undernourishment (Ilemobade 1976, Leeflang 1977, Uilemberg 1983). These authors all agreed that this might be due to a release of latent infection or stress factors aggrevating a mild or subclinical primary infection or a reinfection.

In this outbreak, it is very unlikely that the animals picked up a new infection from the pasture which had fallowed for 2 years prior to restocking.

Also none of the animals left in the unit ( $\mathrm{Ca} 250$ ) was clinically affected. Stress factors that might have aggrevated a latent or subclinical primary infection in this case may be one or a combination of the following:

(a) Change of management from intensive zerograzing to extensive pasturing.

(b) Change of diet from concentrates to dry season low protein pasture.

(c) Higher metabolic rate on pasture as shown in higher growth rate of the animals before first symptoms.

(d) Concurrent helminth infection.

It is interesting that other animals that managed to survived the first six weeks on the pasture did not succumb to heartwater even during the following rainy season when ticks were more than abundant. Heartwater disease has up till the time of this outbreak not been diag- nosed on the farm and no new animals were introduced. The grave impact this outbreak had on an on-going research project necessitated this documentation to alarm other researchers of such a situation.

\section{REFERENCFS}

ANON (1945). Annual Report of the Veterinary Department, Nigeria for the year 1943. Kaduna, Govt. Printers $2.5 \mathrm{p} \rho$.

ILEMOBADE, A. A (1976). Study of Heartwater and the causative agent, Cowdria ruminantium (Cowdry, 1925), in Nigeria. Ph.D. Thesis ABU University, Zaria.

ILEMOBADE, A.A and Leefland, P. (1977). Epidemiology of Heartwater in Nigeria. Rev. Elev. Med. Vet. Pays Trop. 30(2): 149-155.

ILEMOBADE, A. A. and LEEFLANG, P. (1978). Tick-bome disease and their vectors Ed. J.K.W WILD. Center for Tropical Vet. Medicine, Edinburgh, pp. 144-149.

ISONG, T. T., AKPOKODJE, J. U., IKEDF, O.O. and FAYEMI, O. (1974). Heartwater in imported Brown Swiss breed of Cattle in Western Nigeria. Bull. Anim. Hlth. Prod. Africa. 22: 331-334.

LEEFLANG, P.(1977). Tick-borne discases of domestic animals in Northern Nigeria. I. Historical Review, 1925-1966. Trop. Anim Hlth. Prod. 9: 147-152.

UILENBERG, G.(1983).Heartwater (Crowdria niminantium) Infection. Current Stal us. Adv.Vet. Sci. Comp. Med. 27: 427-18t). 